\title{
Conversion of Slope Cropland to Terrace Influences Soil Organic Carbon and Nitrogen Stocks on the Chinese Loess Plateau
}

\author{
Minmin Qiang,3, Jian'en Gao ${ }^{1,2,3,4 *}$, Jianqiao Han ${ }^{1,2}$ \\ ${ }^{1}$ Institute of Soil and Water Conservation, Northwest A\&F University, Yangling 712100, China \\ ${ }^{2}$ Institute of Soil and Water Conservation, Chinese Academy of Sciences and Ministry of Water Resources, \\ Yangling 712100, China \\ ${ }^{3}$ Research Center on Soil and Water Conservation, Ministry of Water Resources, Yangling 712100, China \\ ${ }^{4}$ Research Center of Soil and Water Conservation and Ecological Environment, Chinese Academy of Sciences \\ and Ministry of Education, Yangling 712100, China
}

Received: 4 March 2020

Accepted: 7 May 2020

\begin{abstract}
The change of soil organic carbon (SOC) and nitrogen is vital to farmland ecosystem sustainability after conversion of slope cropland to terrace. Terraces of different ages were selected as subjects to investigate the evolution rule of SOC and nitrogen on the Loess Plateau. The results indicated that SOC density increased from $0.8 \mathrm{~kg} / \mathrm{m}^{2}$ to $1.2 \mathrm{~kg} / \mathrm{m}^{2}$ in 30 -year terrace in $0-20 \mathrm{~cm}$ soil layer and total nitrogen (TN) density increased by $75 \%$. SOC and TN density increased significantly at the initial stage of terraces, and the average accumulation rates were 317.7 and $37.4 \mathrm{~kg} /(\mathrm{ha} \cdot \mathrm{a})$, respectively. SOC and TN density have exceeded the levels in slope cropland in 10-year terrace and greatly improved (by $74.0 \%$ and $107 \%$, respectively) after 30 years,. The greatest soil nutrients and enzyme activity occurred after 30 years. SOC positively related to TN, clay and enzyme activity, while the relationships between SOC and bulk density, $\mathrm{pH}$, and EC were negative. Nitrogen was the major limiting factor of SOC sequestration. Soil environment of long-term use terrace would improve the ability of soil to collect carbon and nitrogen. Terrace has great significance to cropland quality improvement, food security and greenhouse gas emission reduction on the Loess Plateau.
\end{abstract}

Keywords: slope cropland, terrace, soil organic carbon, nitrogen, soil properties

\section{Introduction}

Soil is the largest pool of terrestrial organic carbon in the biosphere [1]. Statistically, the soil carbon (C)

*e-mail: gaojianen@126.com

pool is 3.3 times the size of the atmospheric pool and 4.5 times the size of the biotic pool. The global soil $\mathrm{C}$ pool of 2500 gigatons (Gt) includes approximately $1550 \mathrm{Gt}$ of soil organic carbon (SOC) [2]. Therefore, soil agro-ecological systems are considered potential $\mathrm{C}$ pools. SOC directly affects soil structure and soil fertility, and small changes in SOC will have a large 
impact on the $\mathrm{C}$ cycle [3]. The accumulation rate of SOC is largely dependent on the productivity and composition of vegetation, which is limited by nitrogen in most ecosystems [4]. Recently, nitrogen pools have been suggested as indicators of soil potential $\mathrm{C}$ sequestration [5]. Increasing the SOC and nitrogen pool in farmland is beneficial for soil productivity and environmental health, which has dual importance in promoting sustainable agricultural development and mitigating global warming [6-8].

Soil erosion is the most severe environmental problem on the Loess Plateau and even in the Yellow River basin of China. The Loess Plateau has received widespread attention because of its thick loess and extreme soil and water losses [9, 10]. Terrace construction, an agriculture method used to conserve soil and water, can efficiently reduce soil and water loss from sloping farmlands and can increase yields in arid regions $[11,12]$. Terrace is important with respect to maintaining food security and ecological security in ecologically fragile areas [13, 14]. Four million hectares of terraces have been constructed on the Loess Plateau as of 2012, accounting for approximately 31\% of sloped farmland [15]. Studies have shown that lack of SOC and total nitrogen (TN) is the major limitation to arable land quality and sustainable agricultural development [16]. Moreover, soil and water erosion is the key factor affecting SOC and nitrogen pool losses and degradation of sloping cropland [17]. Studies have also shown that terraces have a significant effect on soil and water conservation, can improve soil quality and promote carbon accumulation in farmland ecosystems $[18,19]$. SOC stocks tend to increase during the early stage of cultivated land reclamation in arid regions [20]. According to the statistical data reported by Lal [21], the carbon sequestration potential in global soil erosion control is 1.47 3.04 Pg/a. However, SOC in agroecosystems is fragile and sensitive to environmental changes and different soil conditions [22]. In addition, research has showed that soil particle composition is closely related to SOC and nitrogen stocks [23]. SOC is also strongly related to soil microbial activity and soil nutrient contents $[24,25]$.
At present, research on terraces on the Loess Plateau has mostly focused on soil quality [26, 27]. However, there are few reports on the effects of land-use change patterns on SOC and TN stocks and the factors causing changes in SOC, especially for the transition from slope cropland to terrace on the Loess Plateau. Therefore, we selected terraces in the Yangjuangou watershed of Yan'an city as typical representatives of agricultural lands to explore the effects of terrace construction on carbon stocks and the factors that cause changes in SOC stocks to determination the regulatory factors underlying the evolution of SOC stocks on the Loess Plateau in a slope-to-terrace context. The development of terraces on sloping land is important in terms of increasing soil carbon storage, improving soil quality, slowing the emissions of greenhouse gases and protecting the eco-environment.

We hypothesized that i) the conversion of slope cropland to terraces would increase SOC and nitrogen stocks on the Loess Plateau of China and that ii) SOC sequestration would be limited primarily by soil nitrogen.

\section{Material and Methods}

\section{Study Area}

The Yangjuangou catchment is located within the central region of Loess Plateau in Shaanxi Province, China $\left(109^{\circ} 30^{\prime} 14^{\prime \prime} \mathrm{E}-109^{\circ} 32^{\prime} 16^{\prime \prime} \mathrm{E}, 36^{\circ} 40^{\prime} 32^{\prime \prime} \mathrm{N}-\right.$ $\left.36^{\circ} 43^{\prime} 28^{\prime \prime} \mathrm{N}\right)$. This catchment covers a total area of $2.02 \mathrm{~km}^{2}$, and its elevation ranges from $1050 \mathrm{~m}$ to 1298 $\mathrm{m}$ (Fig. 1). The region is a typical area with a semiarid continental climate on the Loess Plateau. The slope gradients range from 10 to $30^{\circ}$ [28]. The average annual temperature is approximately $10^{\circ} \mathrm{C}$ and the annual mean precipitation is $527 \mathrm{~mm}$, of which $80 \%$ occurs between May and September with large interannual variability [28]. Droughts frequently occur in the spring and early summer because of low rainfall during this period [29]. The soil in the study area is a silty loam according to the international classification criterion of the USDA

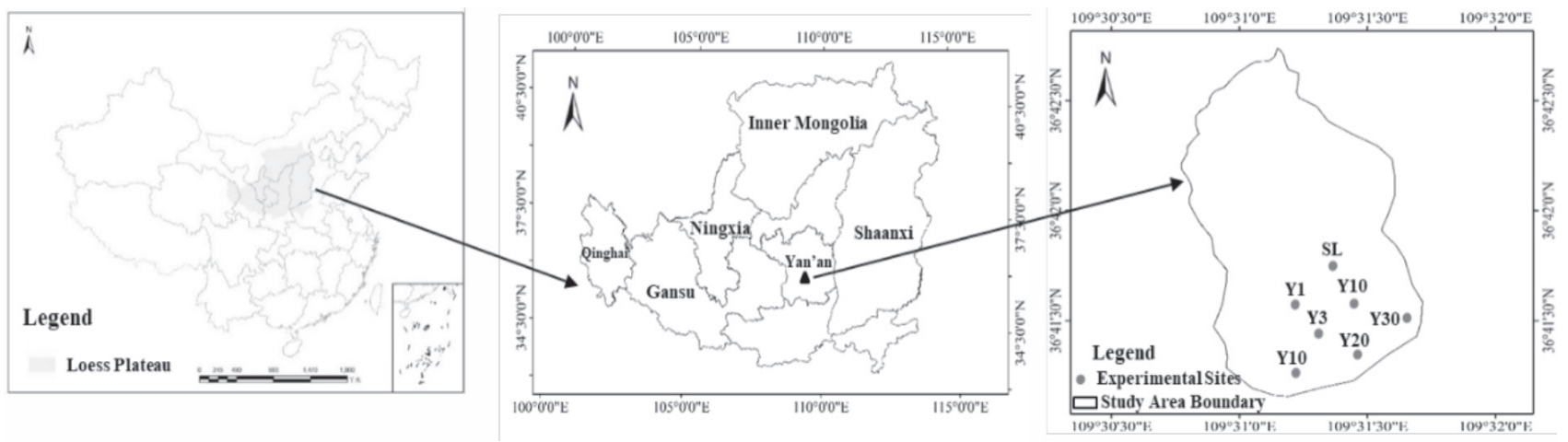

Fig. 1. Location of the study area. SL-slope cropland, Y1, Y3, Y10, Y20, Y30-five terraces at different years (1 a, 3 a, 10 a, 20 a, 30 a), the same below. 
Table 1. Description of the sampling plots.

\begin{tabular}{|c|c|c|c|c|c|}
\hline Sample site & Age/a & Elevation/m & Soil type & Gradient $/{ }^{\circ}$ & Crop \\
\hline SL & 0 & 1175 & Loessial soil & $15 \sim 20$ & corn \\
\hline Y1 & 1 & 1161 & Loessial soil & $0 \sim 5$ & corn \\
\hline Y3 & 3 & 1149 & Loessial soil & $0 \sim 5$ & corn \\
\hline Y10 & 10 & 1148 & Loessial soil & $0 \sim 5$ & corn \\
\hline Y20 & 20 & 1123 & Loessial soil & $0 \sim 5$ & corn \\
\hline Y30 & 30 & 1135 & Loessial soil & $0 \sim 5$ & corn \\
\hline
\end{tabular}

SL: slope cropland, Y1: the first year of terracing, Y3: the third year of terracing, Y10: the tenth year of terracing, Y20: the twentieth year of terracing, Y30: the thirtieth year of terracing, the same below

[30]. The soil has a poor structure and is vulnerable to water erosion. The main agricultural crop species in the area include corn (Zea mays L.) and potato (Solanum tuberosum L.). The growing season of most plant species is from late April to early October. The natural vegetation in the area is provided predominantly by the grass species Artemisia sacrorum, Stipa bungeana and Artemisia scoparia.

The soil type at the sampling sites was essentially the same, and all the land-use patterns were farmland. To avoid errors due to differences in interannual farming, fertilization and management practices, the fieldwork was conducted in October 2017 after harvest. Via the space-for-time substitution method, sampling sites with similar construction methods and management practices and with the same soil parent material were chosen. Slope cropland and five differently aged terraces (1 a, 3 a, 10 a, 20 a, and 30 a) were labeled as SL, Y1, Y3, Y10, Y20, and Y30, respectively (Tab. 1). Rainfall was the main water source for plants in this area.

During the corn growing season, organic fertilizer in the form of cattle fermentative manure (with an average organic matter content $\geq 45 \%$ ) was applied as a basal fertilizer at a rate of $1.12 \times 10^{4} \sim 1.64 \times 10^{4} \mathrm{~kg} \mathrm{ha}^{-1}$ prior to the seeding season, and nitrogen fertilizer in the form of urea was applied at a rate of $725 \mathrm{~kg} \mathrm{ha}^{-1}$ during the flowering period. In addition, during the corn growing season, calcium superphosphate was also applied as a basal fertilizer at a rate of $725 \mathrm{~kg} \mathrm{ha}^{-1}$ before sowing. Single cropping was conducted during successive years, and all corn straw was removed from the field.

\section{Sample Collection and Laboratory Analysis}

In October 2017, samples from south-facing slope cropland and terraces were collected from a $60 \mathrm{~cm}$ soil profile in the Yangjuangou catchment. Three quadrats $(10 \mathrm{~m} \times 10 \mathrm{~m})$ were placed in the upper, middle, and lower regions of the slope cropland $\left(7^{\circ} \sim 15^{\circ}\right)$ and three quadrats $(10 \mathrm{~m} \times 10 \mathrm{~m})$ were randomly placed at each selected terrace site. In each quadrant, five samples were collected and mixed together to form one representative composite sample after all visible residue was removed.
The 0-60 $\mathrm{cm}$ soil depth was divided into three layers: $0-20,20-40$ and $40-60 \mathrm{~cm}$. A total of 90 soil samples were collected and returned to the laboratory. All of the soil samples were collected using a hand auger with a $6.7 \mathrm{~cm}$ diameter. Each sample was subsequently divided into two subsamples: one portion was air-dried, ground and passed through $0.15 \mathrm{~mm}, 1 \mathrm{~mm}$ and $2 \mathrm{~mm}$ diameter mesh screens for soil physical and chemical analyses, and the other portion was stored in a freezer for soil biological property analysis.

SOC was measured by the potassium dichromate oxidation method after digestion with concentrated sulfuric acid [31]. The TN content was determined by semimicro Kjeldahl method, and available phosphorus (AP) was measured by treatment with $0.5 \mathrm{~mol}^{-1}$ $\mathrm{NaHCO}_{3}$ followed by the molybdenum blue colorimetry method using a UV-2300 spectrophotometer (Tianmei Technology Company, China). Ammonia nitrogen (AN) and nitrate nitrogen (NN) were determined by a continuous flow analyzer (AutAnalyel 3, AAA, America). Available K (AK) was determined using a flame photometer (M410, Sherwood, England).

Soil $\mathrm{pH}$ and electrical conductivity (EC) were measured using a conductivity meter (DDS-307A, INESA, China) and a $\mathrm{pH}$ meter (pHS-3E, INESA, China), respectively. The soil bulk density (BD) was determined according to the cutting ring method [32]. Soil particle size was measured using a laser particle analyzer (APA2000, Marvin company, England) by calculating the proportions of sand $(0.05-2 \mathrm{~mm})$, silt $(0.002-0.05 \mathrm{~mm})$ and clay $(<0.002 \mathrm{~mm})$.

Urease activity (UA) was determined via a UV-2300 spectrophotometer (Tianmei Technology Company, China) at $578 \mathrm{~nm}$ [33]. Invertase activity (IA) was measured with 3, 5-dinitrosalicylic acid at a wavelength of $508 \mathrm{~nm}$ [34] and catalase activity (CA) was measured on the basis of the back-titration residual $\mathrm{H}_{2} \mathrm{O}_{2}$, with $0.1 \mathrm{~mol} \mathrm{l}^{-1} \mathrm{KMnO}_{4}$.

\section{Data Analysis}

The specific SOC density (SOCD) at a given profile depth was determined by soil $\operatorname{BD}\left(\rho, \mathrm{kg} / \mathrm{m}^{3}\right)$ and 
organic carbon concentration [35]. The SOCD and the TN density (TND) was calculated [36] as follows.

$$
\begin{aligned}
S O C D & =\sum_{i=1}^{n} S O C_{i} \times B D_{i} \times H_{i} / 100 \\
T N D & =\sum_{i=1}^{n} T N_{i} \times B D_{i} \times H_{i} / 100
\end{aligned}
$$

...where $S O C D\left(\mathrm{~kg} \mathrm{~m}^{-2}\right)$ is the density of $S O C, n$ is the number of soil layers, $S O C_{i}$ is the soil organic carbon concentration $\left(\mathrm{g} \mathrm{kg}^{-1}\right)$ in layer $i, T N$ is the total $\mathrm{N}$ concentration $\left(\mathrm{g} \mathrm{kg}^{-1}\right)$ in layer $i, B D_{i}$ is the soil bulk density $\left(\mathrm{g} \mathrm{cm}^{-3}\right)$ of layer $i$, and $H_{i}$ is the thickness (cm) of layer $i$. This study did not consider the effects of grit volume on SOCD because the soil particles were less than $2 \mathrm{~mm}$.

The $\mathrm{C} / \mathrm{N}$ ratio was calculated as follows:

$$
C / N=S O C / T N
$$

The data were analyzed via the SPSS 20.0 statistical package and Canoco 4.5. One-way ANOVA was used to analyze the effects of terraces of different ages on the measured parameters, and the least significant difference (LSD) test at $\mathrm{p}<0.05$ was used to compare the differences between the treatment means. Principal components analysis (PCA), a statistical procedure, was applied to analyze the factors that influence the SOC and TN stocks on the Loess Plateau. Origin 9.0 was used to construct the figures.

\section{Results and Discussion}

\section{Accumulation Dynamics of SOC and TN}

The results showed that SOC and TN continuously accumulated at the $0-60 \mathrm{~cm}$ depth for 30 years after terrace construction (Fig. 2). The SOC and TN decreased as the soil depth increased from 0 to $60 \mathrm{~cm}$, and the $\mathrm{SOC}$ and $\mathrm{TN}$ at $0-20 \mathrm{~cm}$ were significantly greater than those at 20-40 and 40-60 cm $(p<0.05)$. Compared with slope cropland, the newly constructed terrace (Y1) had lower SOC and TN, but the difference was not significant. After 10 years, the SOC and TN contents of the terraces exceeded those of slope cropland, with increases of $31.8 \%$ and $39.3 \%$, respectively. The SOC and TN increased by $47.3 \%$ and $69.1 \%$ in Y20, respectively, and by $74.0 \%$ and $107 \%$ in Y30, respectively, and the increases were significant $(p<0.05)$.

SOCD within the $0-20 \mathrm{~cm}$ soil layer increased from $0.83 \mathrm{~kg} \mathrm{~m}^{2}$ in slope cropland to $1.22 \mathrm{~kg} \mathrm{~m}^{2}$ in Y30, and the TND increased from $0.08 \mathrm{~kg} \mathrm{~m}^{2}$ in slope cropland to $0.14 \mathrm{~kg} \mathrm{~m}$, reflecting increases of $47.3 \%$ and $75.4 \%$, respectively (Fig. 2). The
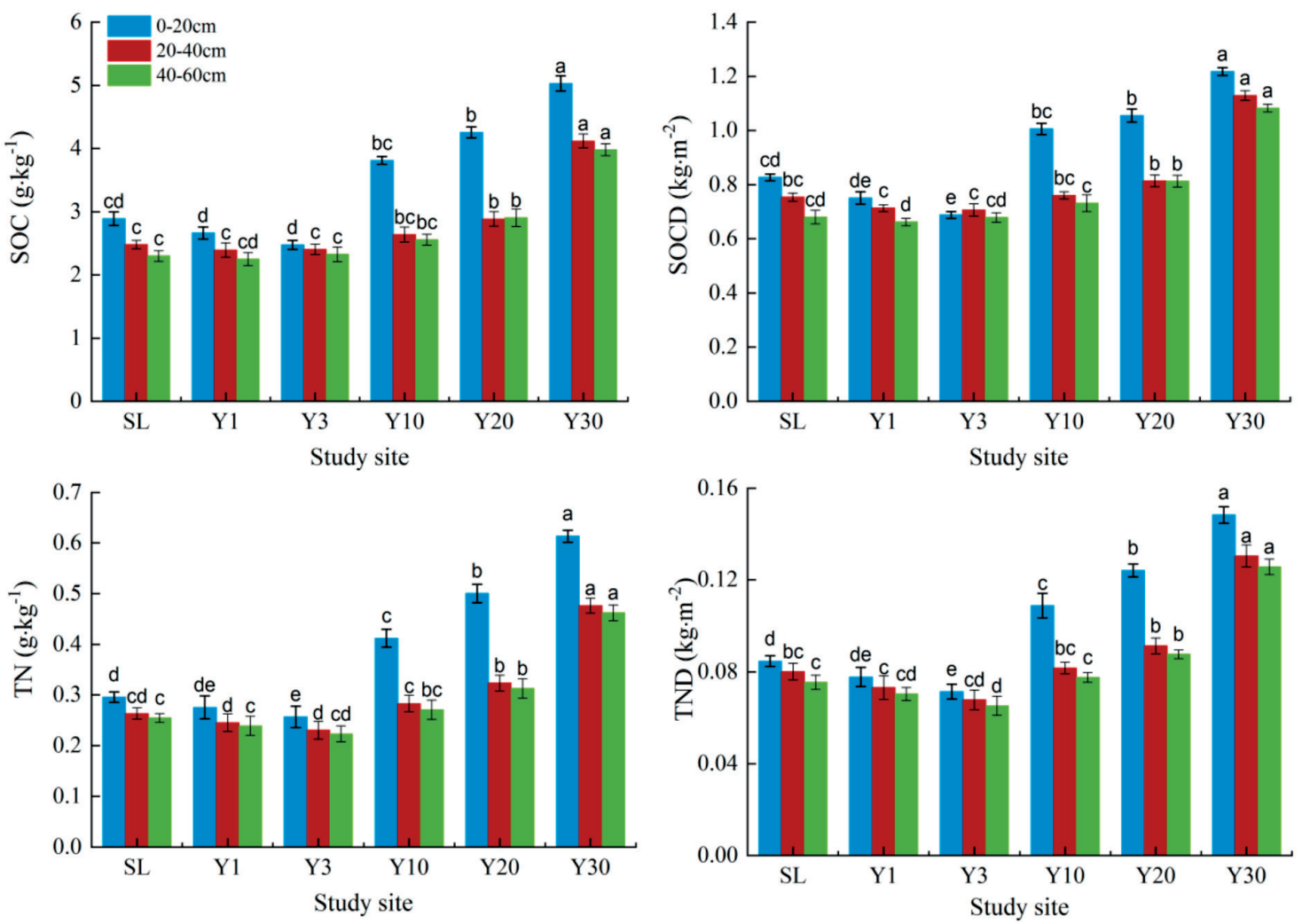

Fig. 2. Variation of SOC, TN, SOCD and TND in the three soil layers at different terrace ages. Different letters mean significant differences between the sample plots in three soil layers $(p<0.05)$. 
Table 2. $\mathrm{C} / \mathrm{N}$ of terrace at different ages in three soil layers.

\begin{tabular}{|c|c|c|c|}
\hline \multirow{2}{*}{ Sample site } & \multicolumn{2}{|c|}{ C/N } \\
\cline { 2 - 4 } & $0-20 \mathrm{~cm}$ & $20-40 \mathrm{~cm}$ & $40-60 \mathrm{~cm}$ \\
\hline SL & $9.77 \pm 0.12 \mathrm{a}$ & $9.41 \pm 0.08 \mathrm{c}$ & $9.03 \pm 0.09 \mathrm{~d}$ \\
\hline Y1 & $9.66 \pm 0.08 \mathrm{ab}$ & $9.76 \pm 0.12 \mathrm{~b}$ & $9.41 \pm 0.11 \mathrm{~b}$ \\
\hline Y3 & $9.64 \pm 0.06 \mathrm{ab}$ & $10.42 \pm 0.09 \mathrm{a}$ & $10.41 \pm 0.06 \mathrm{a}$ \\
\hline Y10 & $9.25 \pm 0.15 \mathrm{~b}$ & $9.31 \pm 0.14 \mathrm{~cd}$ & $9.44 \pm 0.15 \mathrm{~b}$ \\
\hline Y20 & $8.51 \pm 0.13 \mathrm{c}$ & $8.92 \pm 0.06 \mathrm{~d}$ & $9.27 \pm 0.08 \mathrm{c}$ \\
\hline Y30 & $8.20 \pm 0.09 \mathrm{~d}$ & $8.65 \pm 0.11 \mathrm{e}$ & $8.61 \pm 0.12 \mathrm{e}$ \\
\hline
\end{tabular}

Different letters mean significant differences between sample plots in three soil layers $(P<0.05$, Liu's test); Values are presented as mean \pm standard error, the same below

average accumulation rate of topsoil SOCD was $161.8 \mathrm{~kg} /$ (ha a) during the 30 years. Compared with those in the topsoil, the SOCD and TND in the 20-40 and 40-60 cm soil layers accumulated slowly. The SOCD and TND increased most significantly at 3-10 years after terrace construction $(p<0.05)$, and the average accumulation rates were 317.7 and $37.4 \mathrm{~kg}$ / (ha·a), respectively. The SOCD and TND in the terraces exceeded those in the slope cropland at 10 years after terrace construction and greatly increased after 30 years.

SOC and nitrogen are important in terms of soil fertility, eco-environmental protection and sustainable agricultural development [37,38]. The SOC and TN decreased in the first year after slope cropland was rebuilt into terraces, but the decreases were not significant. This trend was likely caused by the different soil mixtures in the different layers in the newly terraced fields [39], as the soils of the sloped cropland had been cultivated and managed for many years. In addition, there was a low level of litter deposition and organic matter input during the first year after the slope cropland conversion into terraces. The SOC and TN in the top layer fully recovered after 10 years and increased thereafter up to 30 years. The SOC in the terrace topsoil sequestered significant amounts of carbon after it had been cultivated for 10 years. There is some evidence that SOC and TN increase after the conversion of sloped cropland to terraces [26,40]. In the present study, the SOC and TN decreased with increasing soil depth. The SOC and TN concentrations in the top layer (upper $20 \mathrm{~cm}$ ) were $48.9 \%$ in 10 -year and $59.9 \%$ in 20 -year terrace, both of which were greater than those in the deeper layers. This result was likely caused by the decomposition of crop residue, which are mainly present with the topsoil [41]. In addition, plant roots, litter and fertilizer are important sources of SOC and other types of nutrient matter in the top layer [42, 43]. Zhang [44] also reported greater SOC and TN stocks in the topsoil layer than in other layers in agro-ecosystems. The results of the current study showed that terrace construction can increase $\mathrm{SOC}$ and $\mathrm{TN}$, as reported previously [45], which directly helps to reduce surface runoff and sediment in areas of soil loss. However, SOC and nutrients in the terraced soil were concentrated mainly within the top layer and were strongly affected by the environment. Kushwaha [46] showed that agroecosystems become frail and sensitive when SOC and TN are largely lost because of improper tillage and management conditions. Therefore, proper cultivation after terrace construction is vital for cropland carbon sequestration and sustainable agricultural development and for the ecological environmental security.

The $\mathrm{C} / \mathrm{N}$ ratio decreased from 9.77 in SL to 8.20 in $\mathrm{Y} 30$ in the $0-20 \mathrm{~cm}$ soil layer, equivalent to a decrease of $16.1 \%$ (Table 2). However, the $\mathrm{C} / \mathrm{N}$ ratio increased first but then decreased in the $20-40 \mathrm{~cm}$ and $40-60 \mathrm{~cm}$ soil layers.

The $\mathrm{C} / \mathrm{N}$ ratio in the three soil layers decreased after the conversion of slope land to terrace in this study. The $\mathrm{C} / \mathrm{N}$ ratios in the $0-20 \mathrm{~cm}$ soil layer decreased from 9.77 in the slope cropland to 8.20 in terrace land rebuilt for 30 years. This is probably due to the extremely severe soil and water erosion in the slope cropland and the accompanying loss of nitrogen on the Loess Plateau, resulting in $\mathrm{C} / \mathrm{N}$ ratios that were greater than those of the terraces [47, 48]. Compared with the terraces, the slope cropland had a weaker degree of soil organic matter decomposition and a low degree of nitrogen mineralization. It was concluded that, compared with the slope cropland, the terraces were more beneficial to SOC sequestration. This may be due to few soil microorganisms and low activity in the terraces [49]. In addition, the effects of climate factors, such as temperature and humidity elevation, could influence the SOC mineralization and mineralization rate [50]. The $\mathrm{C} / \mathrm{N}$ ratios increased from the surface layer to the deep layer at 3 years after the terraces were constructed. This indicates a high degree of soil organic matter decomposition and high degree of nitrogen mineralization [49]. However, Xue [51] studied the effects of different tillage systems on the $\mathrm{C} / \mathrm{N}$ ratio and found that ratio decreased with increasing soil depth in southern China. This may be due to the 

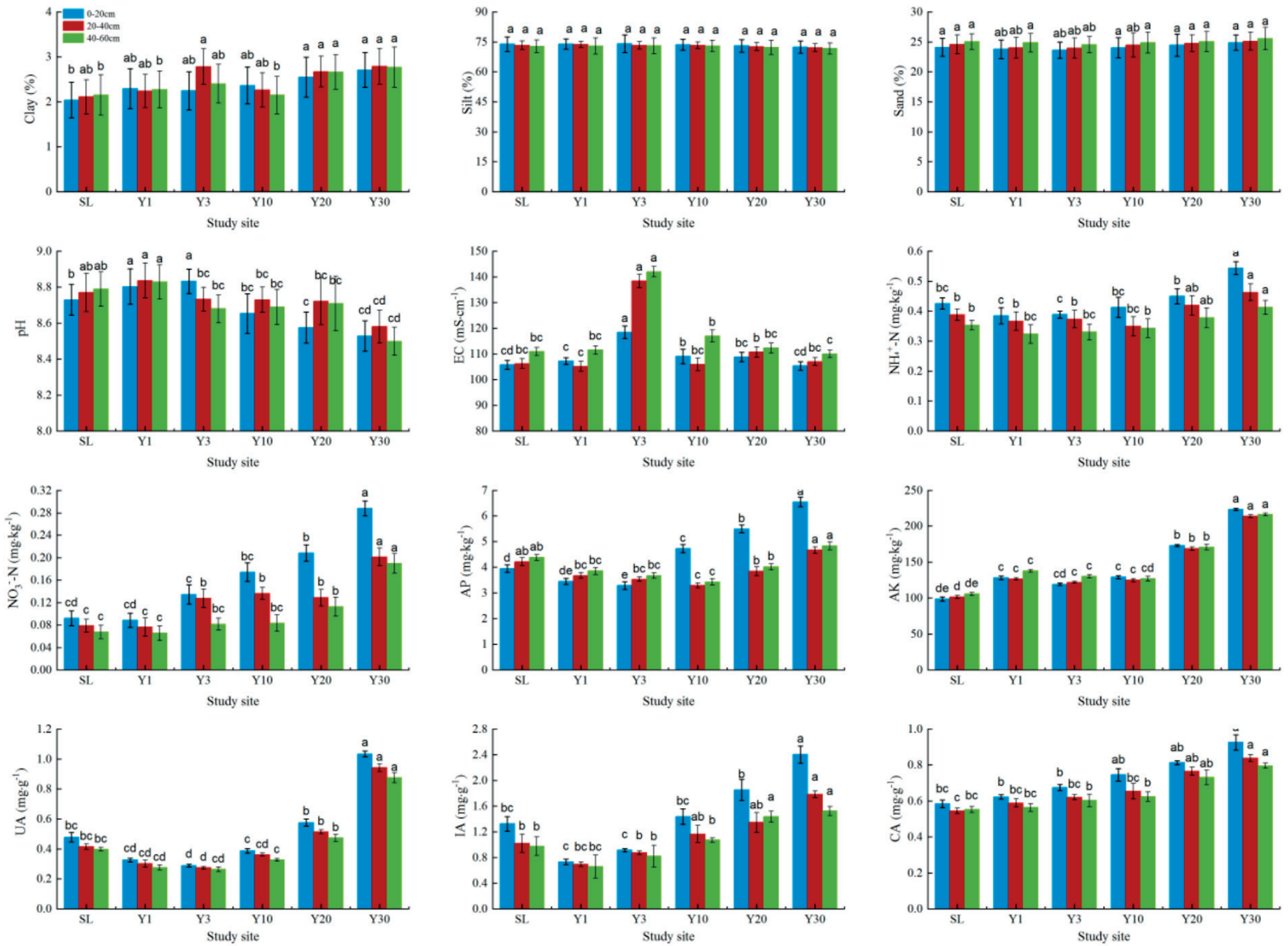

Fig. 3. Variation of soil physical and chemical properties and enzyme activities in the three soil layers at different terrace ages. Different letters mean significant differences between the sample plots in three soil layers $(p<0.05)$.

effects of different degrees of human activities on the mineralization, transportation and crop absorption and utilization of soil nitrogen, which results in differences in SOC and TN concentration and stocks [52].

\section{Characterization of Soil Environmental Factors}

The soil particles were mainly composed of silt (approximately 75\%) and sand (approximately 20\%) (Fig. 3). Compared with those in the slope cropland, the clay particle $(<0.002 \mathrm{~mm})$ content in the terraced land increased from $2.04 \%$ to $2.71 \%$ - an increase of $32.8 \%$. Soil BD gradually decreased in the $0-60 \mathrm{~cm}$ soil layer as the terrace age increased (Table 3). Compared with that in the slope cropland, BD in the terraced land decreased from 1.43 to 1.21 in the $0-20 \mathrm{~cm}$ soil layer and decreased by $15.4 \%$. The soil $\mathrm{pH}$ and EC increased first but then decrease in the $0-60 \mathrm{~cm}$ depth along with the increasing terrace age (Fig. 3). After 3 years, the soil $\mathrm{pH}$ and EC gradually decreased as terrace age increased and recovered to a level similar to those measured in the slope cropland. Compared with those in the slope cropland, the NN, AN, AP and AK contents in the terraced land increased by $212.9 \%, 27.6 \%, 65.8 \%$ and
$127.1 \%$, respectively $(p<0.05)$, in the $0-20 \mathrm{~cm}$ depth (Fig. 3). However, the increases were not significant in the $20-40 \mathrm{~cm}$ and $40-60 \mathrm{~cm}$ soil layers.

Compared with those in the slope cropland, the soil UA and IA activities decreased significantly during the first year in which sloped cropland was terraced $(p<0.05)$, after which the soil UA and IA activities gradually increased (Fig. 3). The soil UA and IA activities in the $0-20 \mathrm{~cm}$ depth increased to a maximum during the 30 years, equivalent to increases of $116.2 \%$ and $81.4 \%$, respectively $(p<0.05)$. The soil catalase activity increased with increasing terrace age, but the increase was not significant in the first 10 years. The soil CA increased by $58.5 \%$ at 30 years after terrace construction.

SOC in agro-ecosystems is influenced by environmental conditions, soil physical and chemical properties, land-use type, and soil management [53, 54]. Changes in $\mathrm{TN}$ in the soil are expected to follow changes in SOC content because more than 95\% of soil nitrogen is usually present in an organic form [55]. Piovanelli [56] found that SOC and TN were strongly correlated under different tillage systems. The results of our study demonstrated that SOC concentrations are 
Table 3. Soil BD of terrace at different ages in three soil layers.

\begin{tabular}{|c|c|c|c|}
\hline \multirow{2}{*}{ Sample site } & \multicolumn{3}{|c|}{ BD $/ \mathrm{g} \mathrm{cm}^{-3}$} \\
\cline { 2 - 4 } & $0-20 \mathrm{~cm}$ & $20-40 \mathrm{~cm}$ & $40-60 \mathrm{~cm}$ \\
\hline SL & $1.43 \pm 0.03 \mathrm{a}$ & $1.62 \pm 0.04 \mathrm{a}$ & $1.48 \pm 0.03 \mathrm{a}$ \\
\hline Y1 & $1.41 \pm 0.01 \mathrm{ab}$ & $1.61 \pm 0.03 \mathrm{a}$ & $1.47 \pm 0.02 \mathrm{a}$ \\
\hline Y3 & $1.39 \pm 0.01 \mathrm{~b}$ & $1.60 \pm 0.01 \mathrm{a}$ & $1.46 \pm 0.03 \mathrm{a}$ \\
\hline Y10 & $1.32 \pm 0.04 \mathrm{c}$ & $1.56 \pm 0.02 \mathrm{ab}$ & $1.43 \pm 0.04 \mathrm{ab}$ \\
\hline Y20 & $1.24 \pm 0.03 \mathrm{~d}$ & $1.52 \pm 0.03 \mathrm{ab}$ & $1.36 \pm 0.02 \mathrm{~b}$ \\
\hline Y30 & $1.21 \pm 0.02 \mathrm{de}$ & $1.37 \pm 0.01 \mathrm{bc}$ & \\
\hline
\end{tabular}

Different letters mean significant differences between sample plots in three soil layers $(\mathrm{P}<0.05$, Liu's test). BD-bulk density.

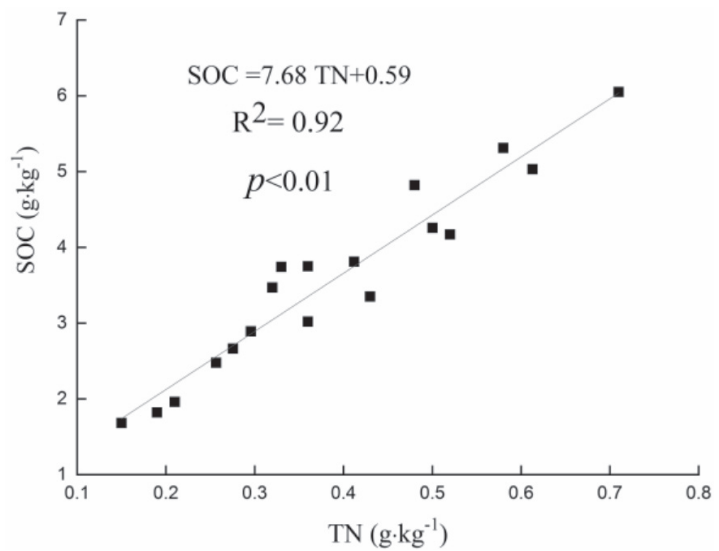

Fig. 4. The relationship between soil organic carbon and total nitrogen. significantly positive related with TN (Fig. 4), which is consistent with the results of previous studies [57]. Most of the terraces with reverse angles on the Loess Plateau can reduce soil and water erosion, increasing the soil water and nutrient contents and improving root development [26]. The continued influence on SOC in the deep layers is beneficial for improving soil fertility and sustainability as a whole. The SOC and TN in each soil layer increased exponentially with increasing terrace age (Fig. 5), and the trend in the topsoil layer was more evident. This showed that the SOC accumulation did not peak under the current management system. The SOC concentrations were negatively related to soil BD. The conversion of slope cropland to terrace can regulate rainfall runoff to conserve soil and water, increase soil ventilation permeability [37], improve soil nutrient
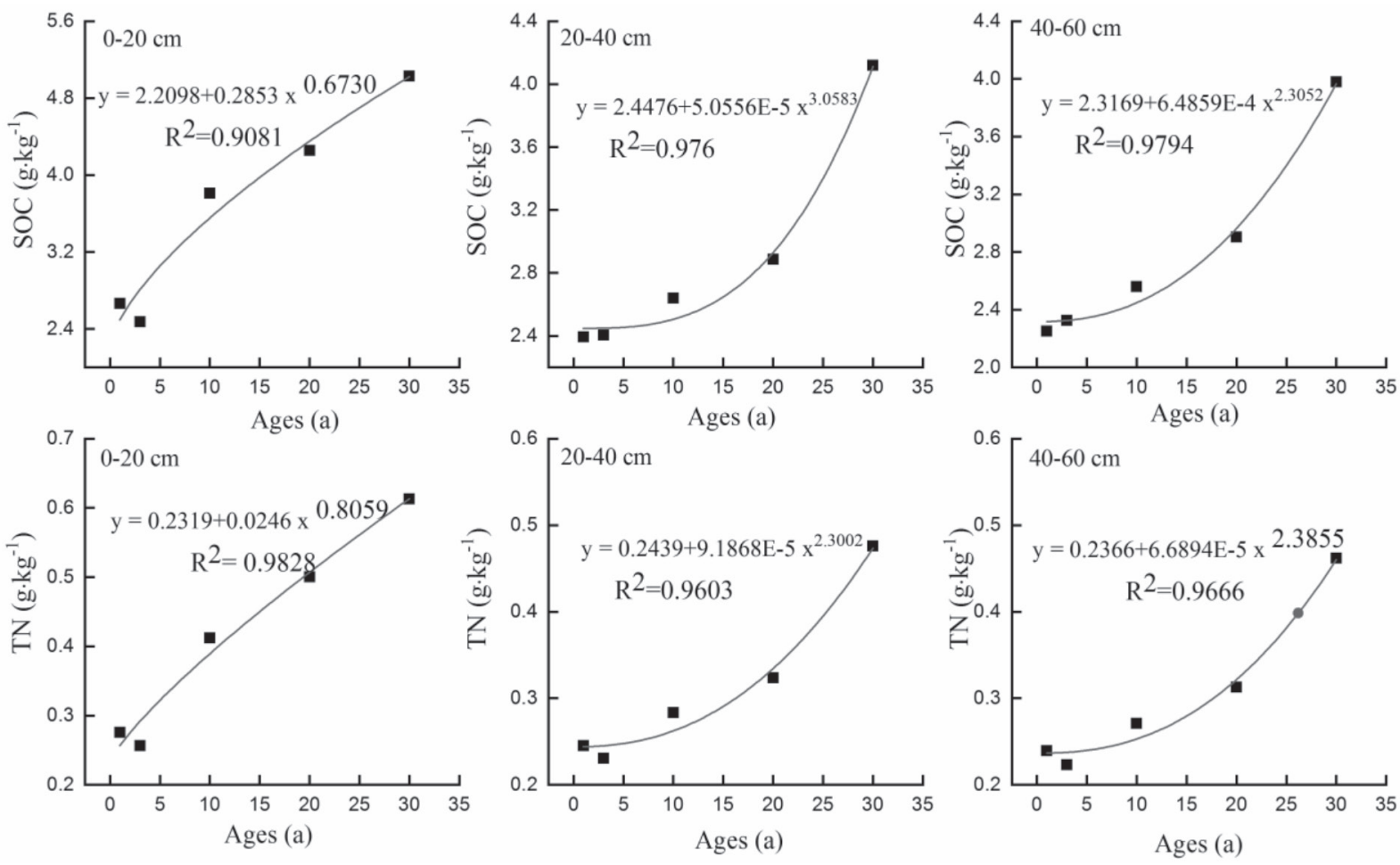

Fig. 5. The correlations of SOC and TN with terrace age at three soil layer. 
status and increase both the quantity and activity of soil microorganisms [26]. The amount of clay in the topsoil layer increased with increasing terrace age.
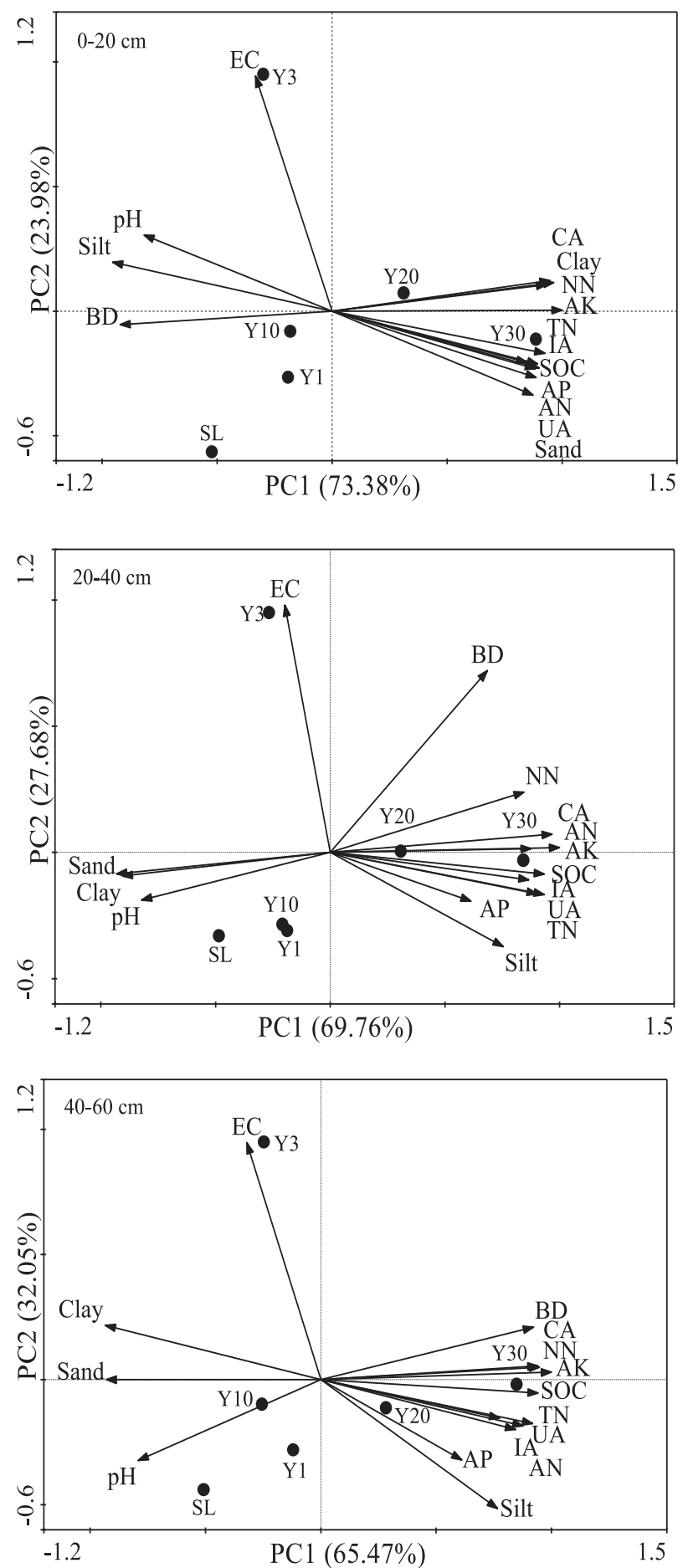

Fig. 6. Principal component analysis (PCA) and the loading values of soil organic carbon (SOC), soil total nitrogen (TN), soil $\mathrm{pH}$ and $\mathrm{EC}$, soil bulk density (BD), soil ammonia nitrogen (AN) and nitrate nitrogen $(\mathrm{NN})$, soil available $\mathrm{P}(\mathrm{AP})$ and available $\mathrm{K}$ (AK) and enzyme activities for terraces at different years and three soil layers. SL - slope cropland; Y1, Y3, Y10, Y20, Y30 -five types of terraces at different years (1 a, 3 a, 10 a, 20 a, 30a); UA - urease activity; IA - invertase activity; CA - catalase activity.

\section{Relationship between SOC and Soil Environmental Factors}

PCA was used to explain the relationship between SOC and soil environmental factors. There was an obvious difference between SL and differently aged terraces according to $\mathrm{PC} 1$ and $\mathrm{PC} 2$ (Fig. 6). At the $0-20 \mathrm{~cm}$ depth, $\mathrm{PC} 1$ and $\mathrm{PC} 2$ explained $73.38 \%$ and $23.98 \%$ of the total variation, respectively. The SOC, $\mathrm{TN}, \mathrm{NN}, \mathrm{AN}, \mathrm{AP}$, and $\mathrm{AK}$ contents and the UA, IA, and $\mathrm{CA}$ were maximal at 30 years after terracing. The loading plot of the soil environmental factors showed that $\mathrm{PC} 1$ was related to soil nutrients, enzyme activities and soil clay, whereas PC2 was related to the soil EC. At the $20-40 \mathrm{~cm}$ depth, PC1 and PC2 explained $69.76 \%$ and $27.68 \%$, respectively, of the total variation respectively. At the $40-60 \mathrm{~cm}$ depth, PC1 and PC2 explained $65.47 \%$ and $32.05 \%$ of the total variation respectively. The loading plots of soil environmental factors were similar to those in the $0-20 \mathrm{~cm}$ depth. The SOC was significantly positive related to TN $(p<0.01)$, and the SOC was positively related to both the soil clay fraction and enzyme activities $(p<0.05)$. However, the relationships between the $\mathrm{SOC}$ content and $\mathrm{BD}, \mathrm{pH}$, and EC were negative.

This study revealed positive relationships between the SOC content and the soil clay fraction, which became significant within 10 to 30 years. Schapel [58] analyzed the influence of the amount of clay and its distribution on the organic carbon content and found that a greater amount of clay led to a lower decomposition rate of SOC and a greater SOC content. It was reported that the increase of SOC in terraces is also beneficial to the formation and stability of soil aggregates, which has a significant effect on soil structure [59]. In addition, soil $\mathrm{pH}$ and salinization can indirectly influence soil carbon pools. This could be due to the effects of $\mathrm{pH}$ and EC on soil nutrient availability and soil microbial activity and quantity [60]. Dissolved organic carbon increases with increasing $\mathrm{pH}$, organic mineral substances are broken down, and the SOC content decreases as a result of acidic conditions [61]. In the present study, the SOC content was significantly and positively affected by the amount of AP and AK and the soil enzyme activity, which is consistent with the results of most studies in semiarid areas of China [62]. This could be due to the promotive effects of phosphate and potash fertilizer on crop root growth, which in turn increased the present content of soil carbon and slowed the consumption of SOC [63]. These results indicate that phosphorus and potassium in the soil are crucial for regulating SOC [2]. Studies have also shown that soil urease is significantly positively related to AK content [64]. Thus, SOC and $\mathrm{TN}$ are influenced by interactions both within and between soil nutrients and enzyme activity. 


\section{Conclusions}

The conversion of slope cropland to terrace decreased the SOC and TN concentrations in the topsoil layer during the first year following the conversion. However, the SOC and TN levels not only restored within 3 years but also surpassed the SOC and TN levels in the slope cropland after 10 years. The SOC and $\mathrm{TN}$ increased most significantly during the initial stage (3-10 a) of terracing, and the average accumulation rates in the $0-20 \mathrm{~cm}$ soil layer were 317.7 and $37.4 \mathrm{~kg}$ / (ha.a), respectively. In the deep layers, the SOCD and TND continued to increase during the 30 year periods.

The soil BD, particle size distribution, soil nutrient contents and enzyme activity fluctuated slightly during the first 10 years in the slope cropland, whereas those in the terrace tended to decrease continuously or increase after 10 years. Our results also showed that nitrogen was the main limiting factor for SOC sequestration in the terraces on the Loess Plateau. Additionally, soil pH, EC and enzyme activity influenced SOC sequestration and nitrogen mineralization. This paper gives the prediction model of SOC concentrations with TN and SOC and TN concentrations with terrace ages. The results suggest that the conversion of slope cropland to terraces and proper management can increase soil carbon stocks. From a single-country or even global perspective, an increase in SOC stocks improves soil quality and reduces carbon emissions, as well as slows global warming.

\section{Acknowledgments}

This paper was supported by the National Key R\&D Program of China (No. 2017YFC0504703), the National Natural Science Foundation of China (No. 41877078, 41371276), the Basic Research Program in Natural Sciences of Shaanxi Province, China (No. 2016ZDJC20), ShaanXi Province Science and Technology Innovation Project (No.2013KTDZ03-03-01), and the Knowledge Innovation Program of the Chinese Academy of Sciences (No. A315021615).

\section{Conflicts of Interest}

The authors declare no conflict of interest.

\section{References}

1. LU N., LISKI J., CHANG R.Y., WU X., JIN T.T., WANG Y.F., FU B.J. Soil organic carbon dynamics of black locust plantations in the middle Loess Plateau area of China. Biogeosciences, 10 (11), 7053. 2013.

2. LAL R. Soil Carbon Sequestration Impacts on Global Climate Change and Food Security. Science, 304 (5677), 1623, 2004.
3. NOVARA A., PISCIOTTA A., MINACAPILLI M., MALTESE A., CAPODICI F., CERDÀ A., GRISTINA L. The impact of soil erosion on soil fertility and vine vigor. A multidisciplinary approach based on field, laboratory and remote sensing approaches. Science of the Total Environment, 622, 474, 2017.

4. JOBBÁGY E.E.G., JACKSON R.B. The Vertical Distribution of Soil Organic Carbon and Its Relation to Climate and Vegetation. Ecological Applications, 10 (2), 423, 2000.

5. HE H., XIA G.T., YANG W.J., ZHU Y.P., WANG G.D., SHEN W.B. Response of soil C:N:P stoichiometry, organic carbon stock, and release to wetland grasslandification in Mu Us Desert. Journal of Soils and Sediments, 19, 3954, 2019.

6. YANG X.M., ZHANG X.P., FANG H.J. Importance of agricultural soil sequestering carbon to alleviate global warming. Scientia Geographica Sinica, 23 (1), 101, 2003.

7. MEYER R.S., CULLEN B.R., WHETTON P.H., ROBERTSON F.A., ECKARD R.J. Potential impacts of climate change on soil organic carbon and productivity in pastures of south eastern Australia. Agricultural Systems, 167, 34, 2018.

8. MA Y.C., LIU D.L., SCHWENKE G., YANG B. The global warming potential of straw-return can be reduced by application of straw-decomposing microbial inoculants and biochar in rice-wheat production systems. Environmental Pollution, 252, 835, 2019.

9. WANG S., FU B.J., GAO G.Y., LIU Y., ZHOU J. Soil moisture and evapotranspiration of different land cover types in the Loess Plateau, China. Hydrology and Earth System Science, 16, 2883, 2012.

10. TENG Y.G., WU J., LU S.J., WANG Y.Y., JIAO X.D., SONG L.T. Soil and soil environmental quality monitoring in China: A review. Environment International, 69, 177, 2012.

11. SUBHATU A., SPERANZA C.I., ZELEKE G., ROTH V., LEMANN T., HERWEG K., HURNI H. Interrelationships between terrace development, topography, soil erosion, and soil dislocation by tillage in Minchet Catchment, Ethiopian Highlands. Land Degradation and Development, 29, 3584, 2018.

12. JIANG C., ZHANG H.Y., WANG X.C., FENG Y.Q., LABZOVSKII L. Challenging the land degradation in China's Loess Plateau: Benefits, limitations, sustainability, and adaptive strategies of soil and water conservation. Ecological Engineering, 127, 135, 2019.

13. XU G.C., REN Z.P., LI P., LI Z.B., YUAN S.L., ZHANG H., WANG D., ZHANG Z.Y. Temporal persistence and stability of soil water storage after rainfall on terrace land. Environmental Earth Sciences, 75 (11), 966, 2016.

14. KOSMOWSKI F. Soil water management practices (terraces) helped to mitigate the 2015 drought in Ethiopia. Agricultural Water Management, 204, 11, 2018.

15. LIU W.Q. Soil and water conservation to be the essential way to the improvement of ecological environment and sustainable development of agriculture in areas of Loess Plateau. Soil Water Conservation in China, 4, 1, 1999.

16. JIANG H.M., JIANG J.P., JIA Y., LI F.M., XU J.Z. Soil carbon pool and effects of soil fertility in seeded alfalfa fields on the semi-arid Loess Plateau in China. Soil Biology and Biochemistry, 38 (8), 2350, 2006.

17. YAO X., YU K.Y., WANG G.Y., DENG Y.B., LAI Z.J., CHEN Y., JIANG Y.S., LIU J. Effects of soil erosion and reforestation on soil respiration, organic carbon and 
nitrogen stocks in an eroded area of Southern China. Science of the Total Environment, 683, 98, 2019.

18. XU G.C., LU K.X., LI Z.B., LI P., WANG T., YANG Y.Y. Impact of soil and water conservation on soil organic carbon content in a catchment of the middle Han River, China. Environmental Earth Sciences, 74 (8), 6503, 2015.

19. RASHID M., REHMAN O.U., ALVI S., KAUSAR R., AKRAM M.I. The effectiveness of soil and water conservation terrace structures for improvement of crops and soil productivity in rainfed terraced system. Pakistan Journal of Agricultural Sciences, 53 (1), 241, 2016.

20. LUO Z.K., WANG E.L., BALDOCK J.A., XING H.T. Potential soil organic carbon stock and its uncertainty under various cropping systems in Australian cropland. Soil Research, 52 (5), 463, 2014.

21. LAL R. World cropland soils as a source or sink for atmospheric carbon. Advances in Agronomy, 71, 145, 2001.

22. WANG X.L., JIA Y., LI X.G., LONG R.J., MA Q.F., LI F.M., SONG Y.J. Effects of land use on soil total and light fraction organic, and microbial biomass $\mathrm{C}$ and $\mathrm{N}$ in a semiarid ecosystem of northwest China. Geoderma, 153 (1), 285, 2009.

23. JIMÉNEZ J.J., LORENZ K., LAL R. Organic carbon and nitrogen in soil particle-size aggregates under dry tropical forests from Guanacaste, Costa Rica - Implications for within-site soil organic carbon stabilization. Catena, 86 (3), 178, 2011.

24. XU M.G., ZHANG X.B., SUN N., ZHANG W.J. Advance in research of synergistic effects of soil carbon sequestration on crop yields improvement in croplands. Journal of Plant Nutrition and Fertilizer, 23 (06), 1441, 2017.

25. SOLEIMANI A., HOSSEINI S.M., BAVANI A.R.M., JAFARI M., FRANCAVIGLIA R. Influence of land use and land cover change on soil organic carbon and microbial activity in the forests of northern Iran. Catena, 177, 227, 2019

26. XUE S., LIU G.B., ZHANG C., FAN L.X. Effects of terracing slope cropland on soil quality in Hilly Region of Loess Plateau. Transactions of the Chinese Society of Agricultural Engineering, 27 (4), 310, 2011.

27. QUINE T.A., WALLING D.E., ZHANG X. Tillage erosion, water erosion and soil quality on cultivated terraces near Xifeng in Loess Plateau, China. Land Degradation and Development, 10 (3), 251, 2015.

28. WANG J., FU B.J., LU N., ZHANG L. Seasonal variation in water uptake patterns of three plant species based on stable isotopes in the semi-arid Loess Plateau. Science of the Total Environment, 609, 27, 2017.

29. WANG J., CHEN Y.Q., SHAO X.M., ZHANG Y.Y., GAO Y.G. Land-use changes and policy dimension driving forces in China: Present, trend and future. Land-use Policy, 29 (4), 737, 2012.

30. LI Y., POESEN J., YANG J.C., F B.J. Evaluating gully erosion using $137 \mathrm{Cs}$ and $210 \mathrm{~Pb} / 137 \mathrm{Cs}$ ratio in a reservoir catchment. Soil and Tillage Research, 69, 107, 2003.

31. BAO S.D. Methods of Soil and Agro-chemical Analysis, $3^{\text {rd }}$ ed.; China Agricultural Science and Technology Press: Beijing, China, 25, 2000 [In Chinese]

32. LIU X., MA J., MA Z.W., LI L.H. Soil nutrient contents and stoichiometry as affected by land-use in an agropastoral region of Northwest China. Catena, 150, 146, 2017.
33. KANDELER E., GERBER H. Short-term assay of soil urease activity using colorimetric determination of ammonium. Biology and Fertility of Soils, 6, 68, 1988.

34. LI Q., SONG X.Z., YRJÄLÄ K., LV J.H., LI Y.F., WU J.S., QIN H. Biochar mitigates the effect of nitrogen deposition on soil bacterial community composition and enzyme activities in a Torreya grandis orchard. Forest Ecology and Management, 457, 117717, 2020.

35. RODRÍGUEZ M.J.A., ÁlVARO F.J., GONZALO J., GIL C., RAMOS M.J.J., GRAU C.J.M., BOLUDA R. Assessment of the soil organic carbon stock in Spain. Geoderma, 264, 117, 2016.

36. GUO Y., WANG X.J., LI X.L., WANG J.P., XU M.G., LI D.W. Dynamics of soil organic and inorganic carbon in the cropland of upper Yellow River Delta, China. Scientific Reports, 6, 36105, 2016.

37. DIACONO M., MONTEMURRO F. Long-term effects of organic amendments on soil fertility. Agronomy for Sustainable Development, 30 (2), 401, 2010.

38. XUE J.F., ZHAO X., SHADRACK B.D., CHEN F., ZHANG H.L. Advances in effects of conservation tillage on soil organic carbon and nitrogen. Acta Ecologica Sinica, 33 (19), 6006, 2013.

39. QIU Y.J., XU M.X., SHI C.D., ZHANG Z.X., ZHANG S. Dynamic accumulation of soil organic carbon of terrace changed from slope cropland in the hilly loess plateau of eastern Gansu Province. Journal of Plant Nutrition and Fertilizer, 20 (1), 87, 2014.

40. SAIZ G., WANDERA F.M., PELSTER D.E., NGETICH W., OKALEBO J.R., RUFINO M.C., BUTTERBACH B.K. Long-term assessment of soil and water conservation measures (Fanya-juu terraces) on soil organic matter in South Eastern Kenya. Geoderma, 274, 1, 2016.

41. LI L.J., HAN X.Z., YOU M.Y., YUAN Y.R., DING X.L., QIAO Y.F. Carbon and nitrogen mineralization patterns of two contrasting crop residues in a Mollisol: Effects of residue type and placement in soils. European Journal of Soil Biology, 54, 1, 2012.

42. SETIA R., MARSCHNER P. Carbon mineralization in saline soils as affected by residue composition, and water potential. Biology and Fertility of Soils, 49, 71, 2013.

43. WANG W.Q., WANG C., SARDANS J., TONG C., JIA R.X., ZENG C.S., PEÑUELAS J. Flood regime affects soil stoichiometry and the distribution of the invasive plants in subtropical estuarine wetlands in China. Catena, 128, 144, 2015.

44. ZHANG T.J., WANG Y.W., WANG X.G., WANG Q.Z., HAN J.G. Organic carbon and nitrogen stocks in reed meadow soils converted to alfalfa fields. Soil and Tillage Research, 105 (1), 143, 2009.

45. ZHANG J.H., QUINE T.A., NI S.J., GE F.L. Stocks and dynamics of SOC in relation to soil redistribution by water and tillage erosion. Global Change Biology, 12 (10), 1834, 2006.

46. KUSHWAHA C.P., TRIPATHI S.K., SINGH K.P. Soil organic matter and water-stable aggregates under different tillage and residue conditions in a tropical dryland agroecosystem. Applied Soil Ecology, 16 (3), 229, 2001.

47. ZHENG F.L., HE X.B., GAO X.T., ZHANG C.E., TANG K.L. Effects of erosion patterns on nutrient loss following deforestation on the Loess Plateau of China. Agriculture Ecosystems and Environment, 108 (1), 85, 2004.

48. CHEN H., ZHANG X.P, ABLA M., LÜ D., YAN R., REN Q.F., REN Z.Y., YANG Y.H., ZHAO W.H., LIN P.F., LIU B.Y., YANG X.H. Effects of vegetation and rainfall types 
on surface runoff and soil erosion on steep slopes on the Loess Plateau, China. Catena, 170, 141, 2018.

49. PARTON W.J., STEWART J.W.B., COLE C.V. Dynamics of C, N, P and S in grassland soils: a model. Biogeochemistry, 5 (1), 109, 1988.

50. GONZÁLEZ-UBIERNA S., LAI R. Modelling the effects of climate factors on soil respiration across Mediterranean ecosystems. Journal of Arid Environments, 165, 46, 2019.

51. XUE J.F., PU C., LIU S.L., CHENG Z.D., CHEN F., XIAO X.P., LAL R., ZHANG H.L. Effects of tillage systems on soil organic carbon and total nitrogen in a double paddy cropping system in Southern China. Soil and Tillage Research, 153, 161, 2015.

52. ANGELA B.H., AMANDA L.M., DAN J.P. Land use effects on gross nitrogen mineralization, nitrification, and $\mathrm{N}_{2} \mathrm{O}$ emissions in ephemeral wetlands. Soil Biology and Biochemistry, 12, 3398, 2006.

53. BATIONO A., KIHARA J., VANLAUWE B., WASWA J. Soil organic carbon dynamics, functions and management in West African agro-ecosystems. Agricultural Systems, 94 (1), 13, 2005.

54. ZHANG F., WANG Z., GLIDDEN S., WU Y.P, TANG L., LIU Q.Y., LI C.S., FROLKING S. Changes in the soil organic carbon balance on China's cropland during the last two decades of the 20th century. Scientific Reports, 7 (1), 7144, 2017.

55. TESFAYE M.A., BRAVO F., RUIZ P.R., PANDO V., BRAVO O.A. Impact of changes in land use, species and elevation on soil organic carbon and total nitrogen in Ethiopian Central Highlands. Geoderma, 261, 70, 2016.

56. PIOVANELLI C., GAMBA C., BRANDI G., SIMONCINI S., BATISTONI E. Tillage choices affect biochemical properties in the soil profile. Soil and Tillage Research, 90, 84, 2006.
57. WANG T., KANG F.F., CHENG X.Q., HAN H.R., BAI Y.C., MA J.Y. Spatial variability of organic carbon and total nitrogen in the soils of a subalpine forested catchment at Mt. Taiyue, China. Catena, 155, 41, 2017.

58. SCHAPEL A., MARSCHNER P., CHURCHMAN J. Clay amount and distribution influence organic carbon content in sand with subsoil clay addition. Soil and Tillage Research, 184, 253, 2018.

59. DENG L., KIM D.G., PENG C.H., SHANGGUAN Z.P. Controls of soil and aggregate-associated organic carbon variations following natural vegetation restoration on the Loess Plateau in China. Land Degradation and Development, 29 (11), 3974, 2018.

60. SONG D.L., TANG J.W., XI X.Y., ZHANG S.Q., LIANG G.Q., ZHOU W., WANG X.B. Responses of soil nutrients and microbial activities to additions of maize straw biochar and chemical fertilization in a calcareous soil. European Journal of Soil Biology, 84, 1, 2018.

61. KAISER K., GUGGENBERGER G., ZECH W. Sorption of DOM and DOM fractions to forest soils. Geoderma, 74 (3), 281, 1996.

62. YANG O., ALAIN N.R., WANG L.X., YAN B.X. Spatiotemporal patterns of soil organic carbon and $\mathrm{pH}$ in relation to environmental factors - A case study of the Black Soil Region of Northeastern China. Agriculture, Ecosystems and Environment, 245, 22, 2017.

63. SIX J., CONANT R.T., PAUL E.A., PAUSTIAN K. Stabilization mechanisms of soil organic matter: implications for C-saturation of soils. Plant and Soil, 241 (2), 155, 2002.

64. HONG C.Q., HE Z.J., YU H.X. Studies on enzyme activities characteristics of dark-brown soil in the three parallel rivers area. Journal of Yunnan Agricultural University, 28 (6), 857, 2013. 
